Dr. Javed Iqbal Wani

Assistant Professor (Law \& Legal Studies)

Centre for Law, Governance and Citizenship,

Ambedkar University Delhi

\title{
Public Order and Popular Protest in Colonial India: Remembering Jallianwala Bagh Massacre after a Century
}

(Working Paper)

In April 2019, it was the centenary mourning of the Jallianwala Bagh massacre which was led by a British officer General Dyer. The Jallianwala Bagh massacre took place in April 1919 and remains one of the most potent memory of British colonial violence and brutality in India. A quick recounting of a representative set of scholarship and observations about the Amritsar massacre of 1919 is mandatory here. In the popular imagination it is referred to as the ultimate example of the cold-hearted character and blood-thirsty approach of the colonialists who knew nothing but oppression. It has been proposed as 'the decisive moment when Indians were alienated from British rule'.1 While Indians were shocked, distressed, disturbed and angered at Dyer's actions, some representative sections of the British were also critical of the excessive use of force at Jallianwala Bagh and termed it as a gross miscalculation but insisted that it was an isolated deviation in the journey of the Empire. 2 Though there are numerous examples of colonial violence across continents, but Jallianwala Bagh massacre acquires a peculiar position given its context, politics and scale. A substantial amount of literature has discussed the horrific incident. Scholars have taken diverse approaches to study the incident and the perpetrator General Dyer. Most literature has attempted either to recount 'Punjab disturbances

\footnotetext{
1 Taylor, A. J. P. (1965) English History 1914-1945. New York: Oxford University Press, p152.

2 Tuteja, K.L., (1997) 'Jallianwala Bagh: A Critical Juncture in the Indian Nationalist Movement', Social Scientist, 25: $1 / 2,25-61$.
} 
of 1919 ' by focusing on the Jallianwala Bagh massacre as an isolated incident or have tried to outline the atrocities of the riotous mobs and the violent atmosphere in Amritsar that resulted in this massacre or have discussed intentions of the infamous General Dyer.

Rupert Furneaux has attempted to absolve the empire of its crimes and instead have argued that it was Dyers medical condition, his arterio-sclerosis, that was responsible for the impaired judgement on the fateful day.3 Nigel Collett has proposed Dyer as a victim of misinformation that led him to make specific conclusions about the 'crowd' and has instead placed the blame on the upper class and the police for providing wrong inputs. 4 However, he did place some responsibility on Dyer and has half-heatedly noted the moral bankruptcy of British imperialism. Some scholars have even tried to offer a different opinion which indirectly whitewashes colonial brutality and even-handedly painted a picture suggesting that British embattled officers were operating in a difficult situation.5 Such scholarship has argued that Dyer panicked because he did not know what he was doing and therefore lied about it afterwards at various occasions. Others have highlighted that there were two different opinions about the Massacre in Britain.6 One, the official opinion, condemned the disproportionate use of force by General Dyer, and there was second, the public opinion which resulted in immense support for Dyer as a British military officer. There exist very few scholars who have offered a critical and comprehensive analysis of the situation. Most recently, Kim Wagner has proposed a more balanced approach and has attempted to understand the form and functions of

\footnotetext{
3 Furneaux, Rupert. (1963) India: Massacre at Amritsar, London: George Allen \& Unwin Ltd., pp 176-177.

4 Collett, Nigel A., (2011) 'The O’Dwyer v. Nair Libel Case of 1924: New Evidence Concerning Indian Attitudes and British Intelligence During the 1919 Punjab Disturbances', Journal of the Royal Asiatic Society, Third Series, 21:4. 469-483.

5 Lloyd, Nicholas, (2011) The Amritsar Massacre: The Untold Story of One Fateful Day, London: I.B. Taurus., Pages 320.

6 Sayer, Derek, (1991) 'British Reaction to the Amritsar Massacre 1919-1920', Past \& Present, No. 131, $130-164$
} 
colonial violence through the Amritsar massacre of 1919.7 None of the analysis have matched the sophistication with which Nasser Hussain had discussed 'martial law' and therefore unmasked the workings of colonial legality that allowed or made such brutality possible.

This article will argue that Jallianwala Bagh did not happen in isolation and must be seen as a continuation of an all India anticolonial mobilisation that had begun a month ago. It will offer two sets of answers. First, it will highlight some analytical insights about public order in colonial India. And second, it will point out that the conduct of officers like General Dyer only reveal the potentiality of sovereign violence. By doing this, it will reveal that Jallianwala Bagh is a great lesson in the study of 'Public order' where an exception could be unleashed without a necessity.

\section{Legality and moral legitimacy: Satyagraha, martial law and the massacre at Jallianwala}

\section{Bagh}

One of the major reasons for the protests that emerged in the year 1919, was the proposed Anarchical and Revolutionary Crimes Act 1919, popularly known as Rowlatt Act or Rowlatt Bills. The 'Rowlatt Act' was passed despite the unanimous opposition of all non-official members of the Imperial Council.s Vast sections of the Indian population and their political leadership became agitated about the Governments' indifference to their opposition to it. As part of the collective response, Mohan Das Karamchand Gandhi started satyagraha on March 23, 1919, to oppose the Rowlatt Act. It was declared that April 6 would be observed as All India Hartal day with twenty-four hours of fasting and suspension of all business. On March 1,

\footnotetext{
7 Wagner Kim, (2016) "' Calculated to Strike Terror": The Amritsar Massacre and the Spectacle of Colonial Violence', Past \& Present, No. 233, 185-225

8 The Madras Mail, Wednesday Evening, March 19, 1919, Page 5, “The Imperial Council, Rowllatt Bill Passed, Madras Member Resigns."
} 
1919, Gandhi in a statement to Press had opposed the Rowlatt Bills. The arguments he made are noteworthy. While taking stock of revolutionary crimes in India, the report of the Rowlatt Committee had opined that secret violence was confined to 'isolated and very small parts of India' and 'to a microscopic body of the people.'9 Gandhi responded arguing that although the existence of such men was truly a danger to society, the Rowlatt Bills would in fact affect the whole of India and its people. For Gandhi, the design of the Bill laid bare a colonial conspiracy of arming the Government with powers out of all proportion to its stated aims. For Gandhi, the Rowlatt Bill was a greater danger than the revolutionary crime itself. He believed that millions of Indians were by nature the gentlest people on the earth and considered the Bills to be 'the unmistakable symptom of the deep-seated disease in the governing body'.10 While pleading with the Government for the use of 'ordinary laws' to deal with revolutionary crime, Gandhi exhorted that a strong 'remedy' like the Rowlatt Bills should only be prescribed once all the milder ones had been tried. This said, the British surely were not likely to listen to his moral advice; instead they were the makers of an empire which had violence at its heart and legality in its head. The anti-Rowlatt Act political mobilisation resorted to Satyagraha. The Satyagraha vow against 'Rowlatt Act' was as follows;

Being conscientiously of the opinion that the Bills known as the Indian Criminal Law (Amendment) Bill No. 1 of 1919 and the Criminal Law (Emergency Powers) Bill No. 2 of 1919 are unjust, subversive of the principle of liberty and justice and destructive of the elementary rights of individuals, on which the safety of the community as a whole and the State itself is based, we solemnly affirm that in the event of these Bills becoming law and until they are withdrawn, we shall refuse civilly to obey those laws and such

\footnotetext{
9 Rowlatt, Sidney Arthur Taylor (1918), Sedition Committee, 1918, Report, Calcutta: Superintendent Government Printing, India, Pages 290.

10 See D.G Tendulkar, Mahatma: Life of Karamchand Gandhi, Vol. 1, Bombay, 1951, Page 251.
} 
other laws as a committee to be hereafter appointed may think fit and we further affirm that in this struggle we will faithfully follow the truth and refrain from violence to life, person or property. 11

Despite nationwide opposition, the Rowlatt Bill was passed into Law on 18 March 1919. It was carried by the 35 Government votes and opposed by 20 out of 25 non-official Indians There were in total 187 amendments proposed by the Indian Members and the official block defeated every one of them.12 Jinnah, Aiyangar, Mazharul Haque, Khaparde, Sunder Singh, Zulfiqar Ali, who all along strongly protested were absent as a protest on the last day of voting. 13 Meanwhile, Gandhi was welcomed in Madras on 18 March and 20 March 1919, by huge mass meeting following his call for satyagraha. Gandhi opposed the Rowlatt Bills but described the character of the western form of Government in a peculiar way in his speech of $20 \mathrm{March}$, which was read by one Mr. Desai because Gandhi was not feeling well. Gandhi's message stated:

By demonstrating to the party of violence the infallible power of satyagraha and by giving them ample scope for their inexhaustible energy we hope to wean that party from the suicidal method of violence. 14

Gandhi's message rejected Sir William's contention that the movement had great potential for evil and retorted that it had only a potential for good. The appeal constituted an attempt to revolutionize politics and to restore significance to moral force. After all, the government did

\footnotetext{
${ }^{11}$ Message sent by Gandhi to Madras meeting, The Bombay Chronicle, 22 March 1919 \& 4 April 1919.

12 Details of some of the amendments can be seen in The Madras Mail, Monday Evening, March 17, 1919, Page 6. "The Imperial Council, The Rowlatt Bill, Plethora of Amendments."

13 For discussion regarding the character of Rowlatt Bills and the positions on Indian members see, The Tribune, Saturday, March 22, 1919, Page 2, "The Rowlatt Bill, A Foregone Conclusion, Position of Indian Members." 14 See, Message sent by Gandhi to Madras meeting, The Bombay Chronicle, 22 March 1919 \& 4 April 1919.
} 
not believe in a principled avoidance of violence or physical force. Gandhi emphasised that the ultimate principle of Western modes of governance which the colonial government of India then also represented, had been succinctly expressed by President Woodrow Wilson in his speech delivered to the Versailles Peace Conference at the time of introducing the League of Nations Covenant where he said:

Armed force is in the background in this programme, but it is in the background, and if the moral force of the world will not suffice, physical force of the world shall.15

Gandhi denounced physical force and affirmed the supremacy of moral force, which according to him India possessed, and the West did not. Though Gandhi had already announced satyagraha the first practical confrontation arrived on 23rd March 1919 when Gandhi gave a call for an 'All India Hartal' for 6th April 191916, against the Rowlatt Act. Gandhi issued four major instructions for the observance of this hartal which included twenty-four hour fasting, suspension of all work other than necessary in the public interest, and finally, public meetings all over India at which resolutions for the withdrawal of these Bills were to be passed.

Another message from Gandhi read to a mass meeting in Madras on 30 March 1919, draws our attention to the framework of his understanding of satyagraha and its relation to law and order. The message read:

A satyagrahi is nothing if not instinctively law-abiding, it is his law-abiding nature which exacts from him implicit obedience of the highest law, i.e., the voice of

\footnotetext{
15 Broader context for Woodrow Wilsons quote can be seen in The Messages and Papers of Woodrow Wilson, (New York, 1924), Vol.2, Page 634.

16 Harendra Nath Mitra, "Punjab Unrest, Before \& After,” Edt., Published by N.N. Mitter, Annual Register Office, Sibpur, Calcutta, April 1920, Pages 433 approx.
} 
conscience, which over-rides all other laws. His civil disobedience even of certain law is only seeming disobedience. Every law gives the subject an option either to obey the primary sanction or the secondary; and I venture to suggest that the Satyagrahi by inviting the secondary sanction obeys the law. He does not act like the ordinary offender who not only commits a breach of the laws of the land, whether good or bad, but wishes to avoid the consequences of that breach.

Initially, Gandhi’s calls for Satyagraha were opposed by some prominent sections like the leftwing of Congress and the leaders of Home Rule, the two major political fronts at that time. This was also a time when Gandhi had not yet become a national leader. It was only after the events of 1919 that Gandhi began to emerge and later dominate the national scene. Some of it can also be attributed to the manner in which events unfolded. What distinguished Gandhi from many others was his political approach. The element of obedience and discipline is noticeable in Gandhi's exhortations. Gandhi was quite aware of the scope of exceptional laws yet moralised conduct by referring to conscience. He appealed to the masses to accept the consequences of law rather than avoiding them.

Satyagraha committees were formed in every part of India. The Satyagrahis of Delhi under the guidance of Swami Shraddhananda, who was popularly known as Mahatma Munshi Ram of the Haridwar Gurukul School, made arrangements to observe Sunday, the 30th March, as a day of self-humiliation and prayer among the citizens of Delhi. This was also a protest meeting against the Government's passing of the Rowlatt Bills.17 On 30th March, as proposed by the Delhi Satyagrahis, no shops were opened and the few that did, speedily closed at the requests

17 The Independent, Wednesday, March 26, 1919, Page 1, "The Black Act Day, Day of Humiliation and Prayer, A Twenty-four Hours Fast, Mr. Gandhi’s Recommendations, Effective Public Demonstration.” 
of the organisers. After the organisers had accomplished a shut-down of baazaars and transport, some workers proceeded to the railway station to persuade the shopkeepers there to comply with the call for hartal. These shopkeepers refused to close their shops arguing that they were bound by their contracts to keep their shops open. This resulted in an altercation, resulting in a minor clash after which the police took two of the demonstrators into custody. Delhi was already observing hartal, and the news of the arrest led to more people rushing to the spot to request the release of the arrested, which was refused. Police caned the demonstrators and as a result a proper clash ensued. When the police were unable to control the growing size of the protest intimation was sent to the administration seeking instructions on how to handle the situation. By noon, an Additional District Magistrate arrived at the spot with a small military force and two machine guns. He ordered the protestors to disperse which was not obeyed. Following this, the machine gun was fired first in the air and then on the protestors killing a few and wounding more. The crowd withdrew to the Queen's Garden, Clock tower and Chandni Chowk area. The protestors then tried to enter the garden of the municipality to form a procession but the military guarding the building fired at them killing a few and wounding many more. This was an extreme response from the authorities. The number of dead was around eight. Mahatma Munshi Ram arrived on the spot and pacified the protestors by explaining to them what had happened. By the afternoon the number of protestors had reached around ten thousand. The District Magistrate and the Commissioner were expecting more violence from the protestors and told Mahatma Munshi to at once call off the gathering as it posed a danger to public peace. Mahatma Munshi explained to them that the gathering will only observe peaceful protest and took the responsibility for peace and order in case any untoward incident happened thereafter. After Mahatma Munshi Ram pleaded with the crowd to follow the principle of satyagraha and protest non-violently, the crowd agreed to observe a peaceful protest. This meeting despite experiencing military firing and deaths concluded with 
a peaceful passing of a resolution of protest against the Rowlatt Bills and the meeting terminated and later dispersed by 6 P.M. 18 Notably, Mahatma Munshi's request had more authority on the angry protestors than the colonial administration which had the means to use extreme violence. Hence, the state had the claim to the monopoly over the use of physical force, it surely did not have similar monopoly to exercise authority and control over the population during popular protests.

\section{Colonial rage and disproportionate violence}

The day following the military firing on the protestors there was tension in the city. People confronted police and demanded dead bodies of those killed in firing, and in protest refused to open their shops. After much pleading and soliciting by the people, the Chief Commissioner Mr. Barron ordered the release of the dead bodies. Delhi mourned on 31 March 1919 and both Hindus and Muslims cremated and buried their dead respectively with thousands participating in the funerals.19 Later in the evening, a conference of citizens was held when a commission of private and independent enquiry into the incident was constituted. It consisted of Rai Saheb Piyare Lal, Hazi-ul-Mulk, Hakim Ajmal Khan, Rai Bahadur Sultan Singh and others and was to record evidence and to report on the facts. A committee of 16 members was also appointed to help them secure evidence for the preparation of this report. Gandhi, who was visiting Madras at the time issued a statement to the press and condemned the firing on Delhi

\footnotetext{
18 For a complete reporting on the Delhi firing see, The Madras Mail, Tuesday Evening, April 1, 1919, Page 5, "Satyagraha Day, Exciting Times in Delhi, Soldiers Fire on Protestors."; The Madras Mail, Wednesday Evening, April 2, 1919, Page 5, "Satyagraha Day, Delhi Riots, Further Details"; Times of India, Tuesday, April 1, 1919, Page 7, "Sequel to Satyagraha, Rioting at Delhi"; Times of India, April 2, 1919, Page 9, "Rioting at Delhi", Also on the same page "The Delhi Tragedy, Facts and Comments"; Times of India, Friday, Aril 4, 1919, "Situation in Delhi"; Times of India, Saturday, April 5, 1919, "Situation in Delhi, Official Report", Amrita Bazar Patrika, Wednesday, April 2, 1919, Page 4, "Satyagraha Demonstration, A Day of National Mourning, Observance All Over Country"; Amrita Bazar Patrika, Sunday, April 6, 1919, Page 4, "The Delhi Tragedy, Official Report"; The Independent, Wednesday, April 2, 1919, Page 7, "The Delhi Tragedy."

19 The Independent, Thursday, April 3, 1919, Page 1, "The Delhi Tragedy, Impressive Funeral Processions, Alleged Use of Ball Cartridges."
} 
protestors.20 He said that 'local authorities in Delhi have made use of a blacksmith hammer to crush a fly.'21 The Delhi Satyagraha Sabha decided that the City has already suffered in the Hartal of 30 March and should be spared participation in the hartal planned for 6 April 1919. But on 6 April Delhi observed a total shutdown like the rest of India. People defied government orders by organising mass gatherings and distribution of prohibited satyagraha newspapers. Following the success of 6 April hartal, Gandhi issued a message, which said:

We are now in a position to expect to be arrested at any moment. It is therefore necessary to bear in mind that if anyone is arrested, he should, without causing any difficulty, allow himself to be arrested, and if summoned to appear before a Court, he should do so. 22

Larger part of this message directed people not to offer any defence or engage any pleaders, in case arrested. It also advised that if fines were imposed as alternative to imprisonment, people should opt for imprisonment.23 In a characteristic note, Gandhi also wanted the satyagrahis to follow prison rules if arrested, because he stated that the current campaign did not aim to make prison reforms. His emphasis could be understood as an attempt to emphasise that by following the law, the truth of the illegitimacy of colonial law could be highlighted. His advice was to first violate the 'untruthful' law in the service of upholding truth- satyagraha- by means of peaceful protest in the first place yet follow the rules once a prisoner in Jail. Gandhi appears to be quite aware that challenging colonial law through simple, straightforward and precise issues

\footnotetext{
20 See, The Independent, Saturday, April 6, 1919, Page 7, The Delhi Tragedy, Mr. Gandhi's Congratulations, Hindu Muslim Union."

21 Amrita Bazar Patrika, Sunday, April 6, 1919, Page 4, "Delhi Tragedy, Mahatma Gandhi’s Message, Blacksmith's Hammer to Crush a Fly, Appeal for self restraint."

22 The Independent, Wednesday, April 9, 1919, Page 6, "Opening of Satyagraha Campaign, Laws regarding Prohibited Literature and Newspapers, Registration to be Civilly Disobeyed."

23 The Independent, Saturday, March 1, 1919, Page 1, "The Anarchic Measures, To Be Fought with Satyagraha, Campaign enunciated in Bombay, 'Refuse Civilly to Obey'."
} 
could bring success to the anticolonial protests. The political move to hold an all India hartal on the basis of satyagraha protests against colonial repression exposed the myth of the strong colonial laws. It enabled the emergence of a unique counter-tactic- satyagraha- to challenge the basis of colonial legality.

The most prominent of these All India Hartals was the one at Lahore in the Punjab. On 2 April, the Superintendent of Police issued a notice requiring the convenors of processions and meetings to apply for a license not later than 10 a.m. the previous day. The Government, passed orders against two popular leaders Dr. Satyapal, who was a medical practitioner, and Dr. Saifud-Din Kitchlew, who was Bar-at-law, prohibiting them from addressing any public meetings.24 On satyagraha day i.e., 6 April, a meeting was scheduled at Bradlaugh Hall, which generated a difference of opinion among the local leaders after the administration put official pressure on them to abandon the event. On 2 April, a meeting was called to deliberate and finally two options were proposed. One moved for the cancellation of the Bradlaugh Hall meeting while the other urged that the meeting should go ahead as planned given that the protest against the 'Rowlatt Act' was far more important than any other consideration. The proposals were put to vote and the latter proposal to go ahead with the meeting was adopted 18 to 2 . As per the plan, on 6 April all businesses were suspended in Lahore and shops were closed without exception. The leaders of hartal in Lahore managed to keep the situation largely peaceful despite the intensity of the agitation and slogans against the Rowlatt Act. The participation of Hindu, Muslims and Sikhs in large numbers was a salient feature of the protest. The Bradlaugh Hall meeting, which was supposed to take place at 5 P.M., began earlier as the Hall was packed. Three overflowing meetings were also held simultaneously in the adjoining

\footnotetext{
24 These leaders were already active organizing public meetings and protests against the Rowlatt Bills in Punjab. One of the earlier grand mobilizations by them can be noticed in, The Tribune, Tuesday, March 11, 1919, Page 2, "Rowlatt Bills, Punjab's Protest."
} 
grounds outside the hall. At the meeting, a resolution was passed entreating the King Emperor to disallow the measure because it constituted an immediate insult to millions of his lawabiding and loyal subjects in India. Three more resolutions were also passed. They voiced a disapproval of the repressive orders against Dr. Satyapal, Dr. Kitchlew and others, strong disapproval of the recent firing on unarmed civilians by the Delhi authorities and finally, a resolution requested the President of the meeting to forward resolutions passed to the Secretary of State for India, the Viceroy, and the Lieutenant Governor of the Punjab.

Mahatma Gandhi was supposed to reach Delhi on 9 April from Bombay. But he was arrested at an earlier station Palwal and sent back to Bombay. He was ordered neither to enter Punjab nor Delhi but to restrict himself to Bombay. The news of Gandhi's arrest spread like wildfire and caused great resentment amongst people in Lahore, Amritsar and Delhi.25 It was alleged that Gandhi was arrested on instructions from the Punjab Government.

The Government in Punjab intended to break the momentum of satyagraha in the province. The Deputy Commissioner Amritsar called the popular leaders Dr. Satyapal and Dr. Kitchlew to his house where they were immediately arrested. News of their arrest spread quickly, and all the shops shut by noon. By 12.30 p.m. a large procession was organised which marched towards the residence of the Deputy Commissioner Amritsar with a view to make a representation for the release of their leaders. The protestors were fired upon and forced back. Meanwhile, another huge group of protestors went to the business area of the city. They burnt the National Bank, the Chartered Bank, the Alliance Bank, the Town Hall, the Mission Church and the Depot of the Punjab Religious Book Society. They also attacked and killed European

\footnotetext{
25 The Independent, Saturday, April 12, 1919, Page 7, "Mahatma Gandhi’s Arrest, Scenes on the Train and on the
} Station, By an Eye Witness." 
officials (Mr. Stewart and Mr. Scott) of the National Bank and (Mr. G.M. Thomson) of the Alliance Bank.26 The telegraph office was attacked which was rescued by soldiers from a Pathan regiment sent to the spot. Dr. Easdon, a Lady Doctor working in the Municipal Zenana Hospital was also attacked. She had to hide in a closet for hours after being rescued by her Indian friends. Seargent Rowland, a cantonment electrician was killed near Rego Bridge while he was walking towards the Fort. The railway guard Robinson, an ex-Northumberlander Fusilier was beaten to death with lathis in the goods yard. Another woman, Nurse Sherwood was also injured. The situation in Amritsar was now out of hand. Europeans were terrified and running for their lives and any of them unfortunate enough to be spotted was dealt with immediately by the rioting protestors. Most pertinently, the official documents and the newspaper reports about the Europeans attacked or killed during the protests, had their names mentioned whereas Indians who were killed by the police or military remained nameless and were referred to simply as 'the mob' or 'the crowd' in subsequent government reports.

When the riot occurred the Garrison in Amritsar consisted of one company of Somerset Light Infantry under the charge of Captain Massey, half a company of Garrison Artillery and the 12th Ammunition Column. Additional forces were mustered to control the situation. A Company of the 9th Gurkhas enroute to Peshawar was stopped and armed under the Command of Captain Crompton who used them for patrolling streets and roads. Another company of the 6th Sussex Regiment from Lahore and the 24th Baluchis under the command of Major Donald was deployed. In addition to this, more troops from Jullundur including the 25 th Londons were also deployed.27

\footnotetext{
26 The Independent, Sunday, April13, 1919, Page 7, “Amritsar Disturbances, 3 Europeans Reported Killed, 'C\&M Gazette's Version', 'Excitement Caused by Local Leaders Arrest'."

27 Most of the official details can be seen in April 1919 issues of Civil and Military Gazette. Only Civil and Military Gazette was allowed to cover the disturbances in Punjab. The rest of the Press could only use official information from the C\& M Gazette.
} 


\section{The Arrival of the Dutiful Butcher}

On 11 April, the next day, the entire city was surrounded by the British and Indian troops and late in the evening Brigadier General Dyer reached Amritsar. By 13 April 1919, Amritsar was under Martial law. 28 As disturbances spread to other parts of Punjab, Martial Law was declared by the Punjab Government on 15 April 1919. The martial law was declared following a communiqué issued by the Home department of the Government of India a day before. It was known as the Martial Law Ordinance or Ordinance No. 1 of 1919 and came into operation on the night between 15 and 16 April 1919. This ordinance provided for the takeover of local law and order administration by the military authorities. Such a law was the proof that the civil administration in Punjab had failed.

The fear of Ghadar was still haunting the colonial administration. Offences were to be tried now by Commissions appointed by Local government comprised of persons who had served as Session Judges and Additional Sessions judges for a period of not less than three years or Judges of the High Court. These Commissions had all the powers of a general Court Martial under the Indian Army Act 1911. The finding and sentence of such a Commission was not to be subject to the confirmation by any authority. In short, it was an imposition of military authority over the region of Punjab in response to the extremely violent riots of 10 April 1919.

As stated above, Martial Law was declared in Punjab province on 15 April 1919, but Amritsar was already under martial law since 13 April.29 April 13 coincided with the religious festival

\footnotetext{
28 The Independent, Tuesday, April 15, 1919, Page 1, "Prussianism in Punjab, Publication of Accounts of Disturbances Prohibited."

29 The Independent, Thursday, April 17, 1919, Page 7, "Martial Law in Lahore and Amritsar."
} 
of Baisakhi. The stated purpose of declaring Martial Law in Amritsar on 13th was to prevent a further escalation of violence. The panic-stricken officials were ready to deal with any 'mob excess'. Since 11 April 1919, Amritsar was under military control. The administration punished the city of Amritsar by depriving it of electricity and water. Evening blackouts were intended to stop people from gathering or moving during the night. Trains stopped third class bookings for Amritsar from the neighbouring towns so that protests did not get outside support. General Dyer also brought more reinforcements to Amritsar. He himself was in command of the 45th Brigade at Jullundur. Before his arrival in Amritsar, he has already sent one hundred British and two hundred Indian soldiers to Amritsar on the request of the local administration. On 12 April he made a round of the city with 120 British soldiers and 320 Indian soldiers and two armoured cars.30 A plane was also hovering in the air. This was a tactic of intimidating the people of Amritsar and to send a clear message to the leaders that the administration had changed and that no one should dare to think of it as any civil administration. This was a warlike situation, but a war that was not fought in the battlefield but simulated on the streets and roads of a city where civil administration had failed. It was a moment of uncertainty for the British colonial government who was scared of the political momentum now that the mask of peace and order under colonial control had shattered. It was a moment when the naked claws of sovereign power and its exclusive right to physical force were on display. The magnitude of confrontation had escalated to a higher level than in usual situations of 'crowd control' involving the police. It was now an absolute distinction between friend and foe, and the defiant population in Amritsar was now declared the enemy.

30 Details of Military Campaign in Punjab were published as an official version of events in the Civil and Military Gazette, whereas other publications were prohibited to publish details of the events unless sourced and produced from the Civil and Military Gazette itself. 
General Dyer while staging his military takeover of Amritsar on 12 April 1919 experienced some confrontation by the protestors in the streets. He made a proclamation warning people against damaging any property and against acts of violence, and against collecting in groups numbering more than four in the streets and other public areas. The next morning, he marched through the street with troops and issued another proclamation under the Seditious Meetings Act, warning the people against assembling and holding meetings, which were declared liable to be dispersed by the force of arms. The same fateful day, 13 April, General Dyer got news that a huge crowd had gathered at Jallianwala Bagh and a meeting was going to be held. He immediately marched towards the spot with 25 British rifles, 40 Gurkhas, 25 Indian rifles, and two armoured cars with machine guns. He arrived at the spot at 5p.m. The Bagh was also a spot for a Baisakhi mela and for this reason many people had come unaware of proclamations and orders. The estimate of the number of people in the Bagh at that time is put between sixteen thousand and twenty thousand. After reaching the spot, General Dyer, so enraged by the defiance of the people ordered firing immediately. It continued for ten to fifteen minutes. People ran in all directions and mostly towards the few narrow exits. Dyer kept directing fire towards the areas where the gathering was the thickest. Firing continued until the ammunition ran out. Altogether 1650 rounds were fired. The Bagh was full of dead bodies and the number ran into hundreds at least. British official figures put the number of the dead identified at 37931 , while the number of the dead claimed by Congress was over a thousand 32 .

Whatever the number of the dead may be, it was enough to be considered a massacre. Dyer did not warn the gathering because the enemy need not be warned but attacked ruthlessly and crushed. Later he submitted to the Hunter Commission that he could have dispersed the crowd

\footnotetext{
31 Nigel Collett, The Butcher of Amritsar, General Reginald Dyer, 2006, Pp 266, 337.

32 Brian Lapping, End of Empire, Palladin, 1985, p 38.
} 
with a warning but then they would have assembled again making a mockery of his orders. This would have resulted in making a fool of himself. Therefore, 'his duty was to fire and fire well'. Most interestingly, General Dyer left the wounded on the spot without any medical assistance. This was nothing short of not caring for the injured and dead of the enemy. Amritsar remained under the protection of 'dutiful' General Dyer for almost a month.

One of the important facts of history is that the martial law was actually proclaimed on April 15, but Dyer believed that martial law came into being ipso facto from the time he took command on 11 April 1919. Dyer held a durbar on 14 April and forced people to open shops even when the city was disturbed and when the people were searching for the dead bodies of their family and relatives. Humiliation of Indians on the streets followed. Flogging for minor offences or defiance in the streets, making people crawl on the streets and ordering them to 'salaam'/salute every European they came across were some of the initial steps General Dyer took after the massacre at Jallianwala Bagh.

The defiant attitude of protestors in Lahore was similar to that in Amritsar. As soon as the news of Amritsar spread, the mood in Lahore turned tense too. The city was already observing protests since the 10th April but now it became more violent. On 11 April the 43rd Brigade headquarters arrived in Lahore and pickets were posted all over the city. On 12 April the military under Col. Frank Johnson was ordered to go into the city taking with him eight hundred men. He entered the city through Delhi Gate and was supported by four planes overhead.33 He entered the city at 9.30 in the morning and left at 1.30 in the afternoon leaving three

\footnotetext{
33 The colonial military campaign against the Punjab disturbances of April 1919 also saw the bombing of civilians by planes. For example, see, The Independent, Friday, April 17, 1919, Page 1, "Fresh Shooting at Amritsar, Crowds Bombed at Gujranwala."
} 
detachments inside the city. He ordered that no detachment should move about unless it consisted of at least two hundred men. The display of military might is quite evident here.

On 13 and 14 April, hartal continued and paralysed the life of the city. On the morning of 15 April at about 11, Col. Frank Johnson issued his first proclamation informing people of Lahore that Marital Law was declared. Lahore remained under Martial Law until the end of May.34 Under Martial Law, orders were passed to immediately lift hartal and resume business. The military authorities began this campaign with Anarkali Bazaar following other markets. Badshahi mosque was closed to the public for six weeks. Minor arrests, flogging of people etc. followed like in Amritsar. As the disturbances were underway in India, the Secretary of State for India presented a draft for the new constitution for India - came to be known as The Government of India Act 1919- to the British Parliament in London. There were expectations in India that at the end of the War there would be colonial reforms in India. This was expected out of India's support to the colonial government during the war. The opposition to Rowlatt Act and the extreme colonial repression in response to it put some pressure on the British parliament.

Owing to the pressure of the anticolonial mobilisation in India in the wake of the upcoming Government of India Act 1919 to be passed later in December 1919, a Disorders Enquiry Committee, also known as Hunter Committee 35 was appointed on 14 October 1919 to enquire into the incident of Jallianwalla Bagh. It began on 29th October and sat for 46 days, 8 in Delhi, 29 in Lahore, 6 in Ahmedabad and 3 in Bombay. Congress was outraged and boycotted it and

\footnotetext{
34 For more details, see "Martial Law Administration in the Panjab as Described by the Official Witnesses, with an introduction by Sir, P.S. Sivaswami Iyer, Published by The Madras Liberal League, 1919.

35 See 'Report of the Disorders Inquiry Committee 1919-20, Government of India, 1920,' published in 'Punjab Disturbances 1919-20, Vol. Two, Seep Publications, Daryaganj, New Delhi, 1976, Pages 275.
} 
instead set up a parallel non-official committee of enquiry.36 The Hunter Committee prepared a report of its findings. The three Indian Members, called the 'minority', dissented from the European majority on some of the wider issues and produced a separate report, which was, however, published in the same volume as the combined report. The difference between them lay in the approach as well as conclusions. The European members held that elements of rebellion were persistent throughout the disturbances. The Indian members conceded that there were certain acts, which 'may amount to waging war in a legal sense', but they could not be described as an 'open rebellion.' The European members stressed the magnitude of the movement and maintained that it might have 'developed into a revolution' with which the Indian members disagreed. Both European and Indian members reacted unfavourably to Dyer's handling of the Jallianwalla meeting and the difference between their reports is one of a degree rather than substance.

The Hunter Committee report criticised General Dyer in two respects: first, that he started firing without giving the people who had assembled a chance to disperse and secondly, that he continued firing for a substantial period of time after the crowd had started to disperse. Dyer himself never suggested any emergency circumstances for the use of firing without warning but expressed that he had made up his mind to shoot.37 Notably, the Hunter Committee report focused more on procedure that could have been followed by General Dyer and ignored the political demands of the anticolonial protests. Following the murder of Europeans in Amritsar during the $10_{\text {th }}$ April hartal, the European community was supportive of the general policy and

\footnotetext{
36 An Urdu compilation of Congress Committee report is by Lala Pandi Das, "Panjab Mein Pehla Marshal Law, Congress Committee ki report," (Urdu), Lahore, Fiction House, 1996, Pages 452.

37 V.N. Datta, "Jallianwala Bagh," published by V.K. Arora, Kurukshetra University Books and Stationery shop, Kurukshetra for Lyall Book Depot, Ludhiana, 1969, Page 118-119.
} 
of Martial Law imposed by the then Lieutenant-Governor of the Punjab, Michael O'Dwyer.38 The element of racism resurfaced again.39 The hartal of April 6, 1919 was the highest point of the Anti-Rowlatt mobilisation. However, the events unfolded in manners unexpected involving violence of unimagined proportions.40 As a result Gandhi had to withdraw his Satyagraha temporarily as he came to the conclusion that the masses did not understand the level of discipline and patience required in such political situations. The Anti-Rowlatt satyagraha was a failure because it failed to stop it. It also failed to enforce non-violent political mobilisation on the masses especially in Punjab. But it did succeed in turning Gandhi into a national leader and satyagraha as a more acceptable and a moral political weapon which was now known and available to millions of colonised Indians.

The Government of India Act 1919 was finally passed. The new constitution did not please the Congress and the Muslim League as it did not meet their demands. As per the new constitution although seats were kept for government and nominated members of the legislative bodies for the first time each body was about to have a majority of elected members. Also, in the central assembly a vast scope for the elected members was given 'to argue', 'make noise' and 'create a fuss' - but they would have no control over the government. All powers of government were reserved to the Governor General/Viceroy and his executive council. The government was not bound by assembly votes nor could it be dismissed by a vote. In the provinces, a half step was taken toward establishing a 'responsible' government. A set up was proposed in which the cabinets would include not only ministers who were elected and therefore were responsible to

\footnotetext{
38 The Punjab Disturbances of April 1919, Criticism of the Hunter Committee Report, by Sir Michael O’Dwyer, with a foreword by The Indo-British Association Ltd. And The European Association of India, published by the Indo-British Association Ltd., 6, Broad Street Place, E.C.2.

39 An interesting take on such issues can be noticed in "Political Problems and Hunter Committee Disclosures, by Alfred Nundy (Bar-at-Law), Published in 1920 and sold at Calcutta- The Publisher, Madras-Messrs. Natesan, Indian Review Press, Lahore- Messrs. Ram Krishna, Anarkali, Allahabad- The Leader Press.

40 For Gandhi and Rowlatt Satyagraha See chapter 5 "The Rowlatt Satyagraha" in Judith Brown, Gandhi's Rise to Power, Indian Politics 1915-1922, London, New York: Cambridge university Press, 1972, pp 160-189.
} 
the councils but also executive councillors who would, as before, be appointed by the governor and therefore only accountable only to him. Under this arrangement, certain portfolios would be 'transferred' and be under Ministers while others would be 'reserved' and be under the executive councillors. The system at the provincial level was termed 'diarchy.'

\section{Conclusion:}

For reasons unknown, Jallianwala Bagh massacre gains precedence while other atrocities during the same period are insufficiently interrogated. The article has proposed that the horrific events of Jallianwala Bagh did not happen in isolation. They were the culmination of a broader 'national' anticolonial mobilisation that had begun almost a month ago. Furthermore, Jallianwala Bagh massacre should be seen as a building momentum of colonial violence that had begun with firing on protestors in Delhi some days ago. Third, the spectacle of violence was not restricted to Amritsar only, Lahore also witnessed repression both before and after the martial law was promulgated. The colonial strategy of maintaining public order by means of violent repression was based on the memory of the uprisings of 1857 followed by the anxiety generated by the Ghadar mutiny which had set the narrative of the rebellious, conspiring and violent native, posing grave danger to not only the safety of European life and property but to the colonial order itself. The culmination of the Amritsar massacre with the institution of an enquiry committee and the passing of the Government of India Act highlights that colonial state was not ready to entertain the native's claim to power. The colonial state held its ground and sustained itself by upholding the sovereign's right to use legitimate physical force. Later, it could absolve itself only by shifting the blame onto a military officer who allegedly had miscalculated the circumstances and had acted in ways that were deemed questionable. 